\title{
TAXATION TREATMENT OF ISLAMIC FinanCE Products in Australia
}

\author{
MARIA BHATTI ${ }^{*}$
}

In October 2010, the Board of Taxation released a Discussion Paper titled Review of the Taxation Treatment of Islamic Finance. Since the release of this Discussion Paper, there has been no legislative reform in Australia to accommodate Islamic finance products. In the Discussion Paper, the Board reviews the taxation treatment of Islamic finance products, such as murābaha. Murābaha is known as 'cost plus profit financing' and involves the sale of a commodity by a financial intermediary to a purchaser at a cost plus mark-up profit rate. The Board argues that in order for a murābaha product to be treated equally to a conventional product for Australian taxation purposes, the profit mark-up component common to murābaha transactions must be treated as if it were interest. However, the Board does not consider the implications for Muslims if the muräbaha profit mark-up is treated as interest. The objective of this article is to investigate the following two questions: can murābaha be viewed as Sharī a-compliant by Muslims if mark-up is treated as if it were interest; and, if murābaha is viewed by Muslims as no longer Sharīa-compliant, could this cause Australia to become less attractive for Muslim investors? This article will undertake a comparative analysis by examining the implications of treating murābaha mark-up as if it were interest from various Australian and UK perspectives. This article argues that before legislative amendments are introduced to cater for Islamic finance products, further research is needed on the Sharī 'acompliant nature of Islamic finance products such as murābaha.

\footnotetext{
* BA/LLB (Melbourne), LLM (Melbourne), PhD Candidate, Law School, Monash University. This article is part of the author's LLM thesis and the author would like to thank her supervisors Professor Tim Lindsey and Dr Sunita Jogarajan for their assistance and guidance in the research. The author is also grateful for the editors and anonymous reviewers of the Deakin Law Review and the author's previous employer, Leanne Abela of Pearsons Lawyers, for providing study leave to enable the author to complete the article and Dr Imran Lum, Associate Director, National Australia Bank, for his constructive feedback on this article.
} 


\section{INTRODUCTION}

In October 2010, the Board of Taxation ('the Board') released a Discussion Paper titled, Review of the Taxation Treatment of Islamic Finance (the 'Discussion Paper'). ${ }^{1}$ This Discussion Paper responded to a recommendation by the Australian Financial Centre Forum (AFCF) that the Board undertake a review of the taxation treatment of Islamic finance products in order to ensure that they are treated equally to 'conventional' financial products. ${ }^{2}$ The AFCF is a joint government-industry partnership set up to progress the government's desire to position Australia as a leading financial services centre in the region.

This article focuses on the Board's discussion of the Islamic transaction known as murābaha $a^{3}$ (the nature of which is explained below) because it is the most commonly used Islamic finance product. ${ }^{4}$ The article will explain the Board's view that in order for a murābaha product to be treated equally to a conventional product, the profit mark-up component common to murābaha transactions must be treated as if it were interest for tax purposes.

There are two issues in particular that this article investigates: 1) can murābaha be viewed as Shari ${ }^{-} a$-compliant by Muslims if mark-up is treated as if it were interest; and 2) if not (that is, if murābaha is viewed by Muslims as no longer Shari ${ }^{\prime} a$-compliant) could this cause Australia to become less attractive for Muslim investors? This article will address these questions by, first, explaining the term 'Shari ' $a$-compliant', the theory behind Islamic banking and finance, and the prohibition of $r i b \bar{a}^{5}$ under Islamic law. Under the heading 'Tax Considerations', this article will then explain murābaha financing and the way it is implemented in Australia. This will lead to a summary of the Board's approach to murābaha. Finally, under the heading 'Present Discourse on the Treatment of Murābaha' the implications of treating murābaha mark-up as if it were interest will be discussed from the various perspectives of Australian

\footnotetext{
${ }^{1}$ Australian Government, Board of Taxation, Review of the Taxation Treatment of Islamic Finance, Discussion Paper (2010) ('Discussion Paper (2010)'.

${ }^{2}$ Australian Financial Centre Forum, Australia as a Financial Centre, Report (2009), 71 [3.6].

${ }^{3}$ This article uses the Arabic transliteration system in: Wilferd Madelung and Farhad Daftary (eds), Encyclopedia Islamica: System of Transliteration of Arabic and Persian Characters (17 March 2013) BrillOnline Reference Works <http://referenceworks.brillonline.com/entries/ encyclopaedia-islamica/system-of-transliteration-of-arabic-and-persian-characterstransliteration>.

${ }^{4}$ Abdullah Saeed, 'Islamic Banking in Practice: A Critical Look at the Murabaha Financing Mechanism’ (1993) 1 Journal of Arabic, Islamic \& Middle Eastern Studies 59, 61.

${ }^{5}$ Usury or interest. Riba $\bar{a}$ is explained in more detail below.
} 
financial institutions and related bodies in comparison to financial institutions in the United Kingdom.

\section{SHARĪ'A-COMPLIANCE}

At a theoretical level, Islamic banking and finance products are considered Shari ' $a$-compliant by Islamic scholars if they follow the principles of Islamic law or Sharì 'a. Sharī 'a literally means 'the way' and Muslims believe that Shar $\bar{i}$ ' $a$ provides 'the way' ${ }^{6}$ or guidance as to how Muslims should live and conduct their lives. Shari ' $a$ law governs the day-to-day lives of people as well as forming the basis of a political, legal, economic and social system that Islamic countries often adopt. ${ }^{7}$ Primarily, Shari ' $a$ law is derived from the Qur'an, the holy book revealed to the Prophet Muhammad, who was the last messenger of Islam, and the sunna, a compilation of the actions and words of the Prophet Muhammad as recorded by his followers (individually called the hadìth). ${ }^{8}$ Sunni Muslims, compromising 80-90 per cent of Muslims, believe in four schools of Islamic jurisprudence, namely Hanafi, Shafi, Maliki and Hanbali. ${ }^{9}$ These four schools of jurisprudence were developed ${ }^{10} 200$ years after the death of the Prophet in order to analyse and interpret Sharī 'a law in light of human need and make rulings on issues that were unclear in the primary sources of Sharī ' $a$ law. ${ }^{11}$ The process through which Sharī' $a$ law is understood is called fiqh, which is literally defined as 'understanding'. ${ }^{12}$ There are various methods by which $\operatorname{Shari}^{-} a$ law is interpreted and legal rulings (fat $\left.\bar{a} w \bar{a}\right)$ are made by Islamic scholars, including: consensus (ijm $\bar{a}$ ), analogy (qiy $\bar{a} s)$, independent reasoning (ijtihād), equity (istihsān) and public interest (maṣlaha). ${ }^{13}$

In the context of Islamic finance products, financial institutions commonly establish Sharī $a$ Supervisory Boards (SSBs): $\operatorname{Sharī’}^{`} a$ advisory boards for the

\footnotetext{
${ }^{6}$ Frank E Vogel and Samuel L Hayes, Islamic Law and Finance: Religion, Risk and Return (Kluwer Law International, 1998) 23.

${ }^{7}$ Ibid.

${ }^{8}$ Ibid.

${ }^{9}$ Farooq A Hassan, 'The Sources of Islamic Law' (1982) 76 American Society of International Law 69.

${ }^{10}$ The four schools of jurisprudence in Sunni Islam were developed by Islamic scholars Abu Hanifa an-Nu'man, Malik Ibn Anas, Muhammad ibn Idris ash-Shafi'i and Ahmad Ibn Hanbal. There is also the Zahiri school of thought, which is only followed by a minority and was founded by Dawud ibn Khalaf al-Zahiri. See generally, Wael B Hallaq, An Introduction to Islamic Law (Cambridge University Press, 2009) 31-7.

${ }^{11}$ Ibid.

${ }^{12}$ Vogel and Hayes, above n 6, 24.

${ }^{13}$ Ibid.
} 
purpose of overseeing compliance with Sharī $a$. For example, the Islamic Bank of Britain has an SSB consisting of Islamic scholars and experts on Islamic finance. ${ }^{14}$ Specifically, the SSBs seek to ensure that Islamic finance products comply with Sharì $a$ law and, if the products are compliant, they are known as Shari ' $a$-compliant products. Typically, an SSB is comprised of a minimum of three to five Islamic scholars who endorse the products as being Sharī $a$ compliant after consulting with each other. ${ }^{15}$ The Shar ${ }^{\prime} a$-compliant products are also audited by the SSBs annually in order to ensure that the products remain Sharì $a$-compliant. ${ }^{16}$

\section{ISLAMIC BANKING AND FINANCE ThEORY}

The main difference between conventional and Islamic finance products is that it is claimed that the latter are free of $r i b \bar{a}$. Further, there are several other qualifications that should be satisfied before an Islamic finance product is viewed as Sharì $a$-compliant. For example, Islamic finance transactions are generally based on a certain and identifiable underlying asset. ${ }^{17}$ This is due to the fact that uncertainty (gharar) and gambling (maysir) are also prohibited. This means that all the terms and conditions of, and any risks flowing from, transactions must be clearly understood by the transacting parties. Items with uncertain existence cannot form the subject of a contract under Sharī $a$ law. Examples of such uncertain transactions include gambling contracts, the sale of goods of unknown value, and the sale of goods which are not yet in one's possession. ${ }^{18}$ Furthermore, money flowing from Islamic finance products can only be invested in industries that are Sharī $a$-compliant. Investments in the alcohol, pornography, gambling and pork industries, for example, are prohibited under Sharī $a{ }^{19}$

14 Islamic Bank of Britain, Sharia Supervisory Committee <http://www.alrayanbank.co.uk /useful-info-tools/islamic-finance/sharia-compliance/>.

15 The process through which the SSBs endorse and audit Islamic finance products is further explained in Maria Bhatti and Ishaq Bhatti, 'Development of Legal Issues of Corporate Governance for Islamic Banking' in Mohamed Ariff and Munawar Iqbal (eds), The Foundations of Islamic Banking: Theory, Practice and Education (Edward Elgar Publishing, 2011) 87.

${ }^{16}$ See generally Hichem Hamza, 'Sharia Governance in Islamic Banks: Effectiveness and Supervision Model' (2013) 6(3) International Journal of Islamic and Middle Eastern Finance and Management 226.

${ }^{17}$ Shayerah Illias, 'Islamic Finance: Overview and Policy Concerns' CRS Report for Congress: Islamic Finance: Overview and Policy Concerns (2008) 2.

${ }^{18}$ See generally, Vogel and Hayes, above n 6, 88-91.

${ }^{19}$ Illias, above $n$ 17, 2. 


\section{A Prohibition of Ribā}

In the Qur'an, the term ' $r i b \bar{a}$ ' is mentioned several times. The earliest verse referring to ribā in the Qur' an was revealed to the Prophet in Makkah around $614 \mathrm{AD}:{ }^{20}$

and, whatever you may give out in riba $\bar{a}$ so that it may increase through other people's wealth, does not increase in the sight of God; but whatever you give by way of charity seeking God's pleasure, will receive manifold increase. ${ }^{21}$

The second rib $\bar{a}$ verse was revealed in Madinah eleven years after the first condemnation in Mecca: 'O Believers! Do not consume ribāa, doubling and redoubling, and fear God so that you may prosper.' 22

The definition of $r i b \bar{a}$ is essential to understanding murābaha and other Islamic finance products. Arabic words in the Qur'an come from root letters that have a meaning in themselves. The root letters of the term $r i b \bar{a}$ are 'Ra-Ba-Waw' ${ }^{23}$ The meaning of these letters put together is 'to grow, increase or prosper' ${ }^{24}$ Many scholars argue that, in the context of Islamic finance, this means the practice of usury or the taking of interest. ${ }^{25}$ Whether ribā should be defined as 'interest' or 'usury' is the subject of growing debate. The roots of usury can be traced back four thousand years and the practice is prohibited in various religions, including Christianity, Judaism and Hinduism. ${ }^{26}$ Usury is distinguished from the taking of interest as follows, '[m]ost nations continue to regulate usury, which is now, in the West, defined as contracting to charge

\footnotetext{
${ }^{20}$ Abdullah Saeed, Islamic Banking and Interest (EJ Brill, 1999) 20.

${ }^{21}$ The Holy Qur'an, English Translation (Chapter 30, Verse 39) <http://www.usc.edu/org/cmje/ religious-texts/quran/verses/030-qmt.php>.

${ }^{22}$ Ibid (Chapter 3, Verse 130).

${ }^{23}$ In Arabic script, the letters are

${ }^{24}$ Fazlur Rahman, 'Riba and Interest' (1964) 3 Islamic Studies 1.

25 See, eg, Muhammad Taqi Usmani, An Introduction to Islamic Finance (Kluwer Law International, 2002); Academy, Islamic Development Bank and Islamic Fiqh, Resolutions and Recommendations of the Council of the Islamic Fiqh Academy 1985-2000 (Islamic Research and Training Institute, 2000); Mahmoud El-Gamal, Islamic Finance: Law, Economics, and Practice (Cambridge University Press, 2006); Mohamad Akram Laldin, Mohamed Fairooz Abdul Khir and Nusaibah Mohd Parid, 'Fatwas in Islamic Banking: A Comparative Study Between Malaysia and Gulf Cooperation Council (GCC) Countries' (2012) Research Paper 31 International Shari'ah Research Academy for Islamic Finance 1.

${ }^{26}$ See generally Constant J Mews and Ibrahim Abraham, 'Usury and Just Compensation: Religious and Financial Ethics in Historical Perspective' (2007) 72(1) Journal of Business Ethics 1.
} 
interest on a loan without risk to the lender at an interest rate greater than that set by the law.' ${ }^{27}$

Mallat accurately notes:

If $[r] i b \bar{a}$ is understood to mean simply usury, then, as long as interest rates have not hit unusual ceilings, all transactions conducted in society are valid. But if [r]iba is in essence defined as interest, then the whole civil and commercial structure of society becomes tainted with illegality. ${ }^{28}$

\section{Qur'an}

A literal reading of Qur'anic verses allows most Islamic scholars to agree that rib $\bar{a}$ is clearly prohibited. Tabari (923 AD), one of the most famous commentators on the Qur'an, comments on this verse, saying that it refers to the way ribā was 'consumed' before the Prophet Muhammad introduced the religion of Islam to the Arabs:

one of them would have a debt repayable by the debtor at a specific date. When the maturity comes the creditor would demand repayment from the debtor. The latter would say, "Defer the repayment of my debt, I will add to your wealth.” This is the rib $\bar{a}$ which was doubled and redoubled. ${ }^{29}$

Thus, Tabari argues that the doubling and redoubling of the principal amount borrowed would lead to an unjust result for the borrower who would owe the lender four times more than what was lent at the outset. ${ }^{30}$

The form of ribā described above refers to a practice known by Muslims as rib $\bar{a}$ al-jahiliyyah. ${ }^{31}$ Ibn Hanbal, founder of the Hanbali school of Islamic jurisprudence, argues that this was the form of rib $\bar{a}$ condemned in the Qur'an when it was revealed to the Prophet Muhammad. ${ }^{32}$ Classical Qur'anic commentary, such as that developed by Zamakhshari (d 1144) and Ibn Kathir

\footnotetext{
${ }^{27}$ Norman Jones, 'Usury’ in Robert Whaples (ed), E H Net Encyclopedia (Economic History Services, 2008) <https://eh.net/encyclopedia/usury/> quoted in Muhammad Ayub, Understanding Islamic Finance (John Wiley \& Sons, 2007) 54.

${ }^{28}$ Chibli Mallat, 'The Debate on Riba and Interest in Twentieth Century Jurisprudence' in Chibli Mallat (ed), Islamic Law and Finance (Graham \& Trotman, 1988) 69.

${ }^{29}$ Abdullah Saeed, 'The Moral Context of the Prohibition of Riba in Islam Revisited' (1995) 12(4) American Journal of Islamic Social Sciences 496, 500.

${ }^{30}$ Ibid.

${ }^{31}$ Ibid 501.

${ }^{32}$ Vogel and Hayes, above n 6, 73.
} 
(d 1373), share this view. ${ }^{33}$ On the other hand, al-Jassas (d 981) defines riba as the lending of money at a 'predetermined sum over the principal amount'. ${ }^{34}$ Since the Qur'an provides limited commentary on the meaning of $r i b \bar{a}$, many scholars turn to the sunna or the tradition of the Prophet Muhammad, which is the second major source of Sharīa $a$ for Muslims.

\section{Sunna}

The tradition of the Prophet Muhammad (sunna) is the second main source of Shari ${ }^{\prime} a$ and the sunna is often recorded in the form of hadìth. The hadìth refers to two types of ribā: ribā al-fadl and riba al-nasiah. Riba al-fadl is based on the saying of the Prophet Muhammad:

Gold for gold, silver for silver, wheat for wheat, barley for barely [sic], dates for dates, and salt for salt should be [exchanged] like for like, equal to equal, hand to hand. If types [of the exchanged commodities] are different, then sell them as you wish, if they are [exchanged] on the basis of a hand-to-hand transaction. ${ }^{35}$

This saying, also referred to as the 'six commodity hadith', prohibits the sale of 'interest of excess' (riba al-fadl). ${ }^{36}$ This means that commodities should be exchanged for cash as opposed to barter because there are differences in quality when barter takes place. ${ }^{37}$ The Prophet prohibited riba al-fadl in order to ensure that no exploitation took place. ${ }^{38}$ There are a number of hadith dealing with riba al-fadl, whereas there are relatively few hadīth dealing with riba alnasi'ah, also known as deferred payment or interest of waiting. Ribā al-nasi'ah stems from the root word nasa'a meaning to postpone, defer or wait. ${ }^{39}$ The waiting period refers to the time that a borrower is allowed to repay the loan. Riba al-nasi'ah is the fixed amount that the borrower has to pay back which consists of the principal amount as well as an additional amount which a bank receives as a reward for waiting. ${ }^{40}$ The contemporary scholarly debate

\footnotetext{
${ }^{33}$ Raquib Zaman, 'Riba and Interest in Islamic Banking' in Mohamed Ariff and Munawar Iqbal (eds), The Foundations of Islamic Banking (Edward Elgar, 2011) 223.

${ }^{34}$ Ibid.

${ }^{35}$ Sahih Muslim, 5:44 as quoted in Saeed, 'The Moral Context of the Prohibition of Riba in Islam Revisited', above n 29, 507-8.

36 This article does not discuss the legal rulings surrounding this hadīth. For a detailed explanation, see Saeed, ibid 496.

${ }^{37}$ Zamir Iqbal and Abbas Mirakhor, An Introduction to Islamic Finance: Theory and Practice (Vanguard Books, 2008) 55-6.

${ }^{38}$ Ibid.

${ }^{39}$ Ibid.

${ }^{40}$ Ibid.
} 
regarding the similarities between ribā al-fadl and ribā al-nasi'ah and modern day interest centres on how the term ' $r i b \bar{a}$ ' is interpreted. The methodology involved in the interpretation of the Qur'an is a long and complex topic that is beyond the scope of this article. However, two methods of interpretation of the term riba in the Qur'an are discussed here, literal and contextual.

\section{$3 \quad$ Literal Interpretation}

Those who read the Qur'an literally generally overlook the context in which verses about ribā are revealed. Ayub takes this approach:

rib $\bar{a}$ includes both usury and interest as used in modern commercial terminology. The word "interest" by and large has now been accepted and is understood as ribā. Conventional banks’ loan transactions carrying interest involve both ribā al-nasiah and riba al-fadl — an extra amount of money is paid at the time when payment becomes due as per the loan contract. ${ }^{41}$

Similarly, Justice Wajihuddin Ahmad, member of the Shariat Appellate Bench of the Supreme Court of Pakistan, states: 'ribā in Islam encompasses every return and all excess arising purely in consideration of time allowed for the use of money or of any other thing of value lent'. ${ }^{42}$

An interpretation that all return and excess is ribā can lead to the conclusion that the entire Islamic finance industry is based on rib $\bar{a}$ because, as will be seen, most Islamic finance products include commissions and fixed fees. ${ }^{43}$ Profit mark-up, commission and fixed fees are viewed by literalists as an addition over the principal. ${ }^{44}$ Literalists include contributors to the Islamic finance industry from the 1950 s to the 1980 s. ${ }^{45}$ For example, Chapra noted in his book published in 1985 that $r i b \bar{a}$ 'has the same meaning and import as interest' ${ }^{46}$ The Islamic Research College in the University of al-Azhar stated at its second annual conference in 1965 that any interest imposed by banks constituted rib $\bar{a}$ regardless of whether the amount was seen as just or unjust, and regardless of

\footnotetext{
${ }^{41}$ Ayub, above n 27, 53.

42 Ibid.

${ }^{43}$ Raquibuz Zaman, 'Usury (Riba) and the Place of Bank Interest in Islamic Banking and Finance' (2008) 6 International Journal of Banking and Finance 1, 6.

${ }^{44}$ Ibid.

${ }^{45}$ Abdullah Saeed, 'Islamic Banking and Finance: In Search of a Pragmatic Model' in Virginia Hooker and Amin Saikal (eds), Islamic Perspectives on the New Millennium (Institute of Southeast Asian Studies, 2004) 113, 117.

${ }^{46}$ M Umer Chapra, Towards a Just Monetary System (Leicester: Islamic Foundation, 1985) as quoted in Saeed, ibid 117.
} 
the context of the loan. ${ }^{47}$ Islamic finance theorist, Uzair, also notes that interest, in all its forms, is forbidden under Shari ${ }^{-} a{ }^{48}$ Similarly, the Council of Islamic Ideology of Pakistan in the 1980s stated, 'there is complete unanimity among all schools of thought in Islam that the term riba $\bar{a}$ stands for interest in all its types and forms' ${ }^{49}$ Furthermore, Maududi (d 1979) states that it is clear from

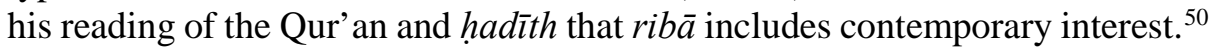
However, according to Visser and Visser, '[i]f one looks at the literal statements, one may be inclined to reject interest totally; people who look at the rationale for an injunction may argue that a ban on riba $\bar{a}$ is justified when charging interest brings injustice and not when it does not. ${ }^{51}$ This argument will now be discussed.

\section{Contextual Interpretation}

Those who understand the riba verses in the Qur' an and the hadīth contextually argue that the prohibition against $r i b \bar{a}$ is not directed at profit but a fixed and pre-determined return on financial transactions. ${ }^{52}$ Saeed uses the term 'pragmatists' for those who interpret ribā contextually, and defines them as those who try to 'balance practical realities with traditional Islamic principles'.$^{53}$ Trade and profit are viewed as positive and natural outcomes of a healthy market in line with the Qur'anic verse: 'God has made trade lawful and has forbidden ribā. ${ }^{54}$ Therefore, many argue that a murābaha transaction is a form of trade, which is lawful. The additional mark-up price that the buyer has to pay is justified as 'profit' and compensation because the seller has been denied the use of the asset and has provided the good to the buyer before payment. ${ }^{55}$ The mark-up rate is calculated by taking into consideration all direct and indirect costs associated with the transaction including the risk of non-

47 Sudin Haron and Wan Nursofiza Wan Azmi, Islamic Finance and Banking System: Philosophies, Principles \& Practices (McGraw Hill, 2009) 186.

${ }^{48}$ Hans Visser and Herschel Visser, Islamic Finance: Principles and Practice (Edward Elgar, 2009) 32.

${ }^{49}$ Council of Islamic Ideology (CII), Consolidated Recommendations on the Islamic Economic System (Islamabad: Council of Islamic Ideology, 1983) 7, quoted in Saeed, 'Islamic Banking and Finance: In Search of a Pragmatic Model', above n 45, 118.

${ }^{50}$ Abdullah Saeed, 'Adapting Understanding of Riba to Islamic Banking: Some Developments' in Mohamed Ariff and Munawar Iqbal (eds), The Foundations of Islamic Banking (Edward Elgar, 2011) 54.

${ }^{51}$ Visser and Visser, above n 48, 32.

52 Vogel and Hayes, above n 6, 203.

${ }^{53}$ Saeed, 'Adapting Understanding of Riba to Islamic Banking', above n 50, 55.

54 The Holy Qur'an, English Translation (Chapter 2, Verse 276) <http://www.usc.edu/org/cmje/ religious-texts/quran/verses/002-qmt.php>.

${ }^{55}$ Vogel and Hayes, above n 6, 203. 
payment and the potential profit sacrificed as a result of the deferred payment. ${ }^{56}$ Although many early Islamic jurists believed that an increase in the sale price could not be justified on the basis of time because time was not considered money, contemporary scholars and Islamic institutions have accepted the time value of money. This has been the subject of much debate and, as Saeed argues, '[m] urabaha finance and the higher credit price involved therein has clearly shown that there is a value of time in muräbaha based finance, which leads, albeit indirectly, to the acceptance of the time value of money. It has been conveniently ignored that acceptance the time value of money logically leads to the acceptance of interest'. ${ }^{57}$

Using the contextual approach, Saeed interprets the verses of the Qur'an and hadith according to the context in which they were revealed. For example, he criticises the approach of various jurists when interpreting the six-commodity hadith mentioned above, which states that goods such as gold and silver can only be exchanged with similar goods and in a hand to hand (on the spot) transaction. ${ }^{58}$ Saeed argues that this interpretation neglects the rationale behind the hadith, and that the reason these goods are mentioned is that gold and silver were the form of money used at the time and the commodities were then essential for survival. ${ }^{59}$ Furthermore, it was common at the time of the Prophet for people to trade at one time a larger amount of wheat of inferior quality for a lesser amount of wheat of superior quality to be delivered and received in the future. This would lead to injustice for poorer people who were paying more than they otherwise would for the commodity. ${ }^{60}$ Thus, Saeed argues that the rationale behind the prohibition of the two forms of rib $\bar{a}$ was

'potential injustice, to the economically weaker party in a barter transaction...' [such as]...cheating an unsophisticated entrant into the market, of any monopsonistic or monopolistic collusion or exploitation designed to lower or raise prices beyond what is justified by market conditions, and of sales involving uncertainty and speculation. ${ }^{61}$

This view is shared by Rida (d 1935) who concluded that the prohibition against rib $\bar{a}$ was revealed at the time of the Prophet Muhammad and does not apply to the forms of interest in the modern world. ${ }^{62}$ Farooq also disagrees with the

\footnotetext{
${ }^{56}$ Ibid.

${ }^{57}$ Saeed, Islamic Banking and Interest, above n 20, 95.

${ }^{58}$ Saeed, 'The Moral Context of the Prohibition of Riba in Islam Revisited', above n 29, 508.

${ }^{59}$ Ibid.

${ }^{60}$ Ibid.

${ }^{61}$ Ibid 509-10.

${ }^{62}$ Visser and Visser, above n 48, 21.
} 
orthodox interpretation of ' $r i b \bar{a}$ ' as 'interest' ${ }^{63}$ His interpretation is that the prohibition on $r i b \bar{a}$ is only valid when the increase on the principal loan is not noted in the initial contract. ${ }^{64}$ This would lead to zulm (the Arabic word for injustice and exploitation). Thus, if riba is read according to the broader Qur'anic context of charity (sadaqah), it is not interest but increase in money (ribā) that leads to zulm and is prohibited. ${ }^{65}$ Fazlur Rahman also looks at the rationale behind the prohibition of $r i b \bar{a}$ and argues that those who interpret $r i b \bar{a}$ as being equivalent to modern day interest fail to understand that the Qur'an historically banned $r i b \bar{a}$ because it was a form of exploitation at the time of the Prophet Muhammad. ${ }^{66}$ Commenting on the views of Farooq and Rahman, Saeed notes that the interpretation that contemporary interest is not riba is not widespread. ${ }^{67}$ This is because most Islamic scholars and academics still view interest as being exploitative in the contemporary economic system. ${ }^{68}$

Many commentators such as Saeed, and Vogel and Hayes note that the rise of the Islamic finance industry occurred after the independence of Muslim countries post-World War II. The end of colonialism and the oil boom through the 1970s brought a degree of affluence and independence to Muslim countries in the Middle East. Islamic finance products were formulated so that they conformed to the modern capitalist economy and were also Sharī $a$ compliant. ${ }^{69}$ In order to formulate them in this way, Islamic scholars had to use a pragmatic approach and look at the context of the rules of riba outlined in the Qur'an and hadith. Islamic banking theorists argued that Islamic banking should be based on Profit and Loss Sharing (PLS) as opposed to interest. ${ }^{70}$ This led to the establishment of the Mit Ghamr Savings Bank in Egypt in the early 1960s and the creation of a number of Islamic financial institutions around the world in the 1970s, such as the Islamic Development Bank in Jeddah. ${ }^{71}$ Among the Islamic finance products introduced, ${ }^{72}$ modern forms of the traditional transactions have gained the most popularity but at the same time generated the

\footnotetext{
${ }^{63}$ Saeed, 'Adapting Understanding of Riba to Islamic Banking: Some Developments', above $\mathrm{n}$ $50,52-3$.

${ }^{64}$ Ibid.

65 Ibid.

${ }^{66}$ Ibid.

${ }^{67}$ Ibid.

${ }^{68}$ Ibid.

${ }^{69}$ Saeed, Islamic Banking and Interest, above n 20, 8-15.

${ }^{70}$ Ibid.

${ }^{71}$ Ibid 9-10.

${ }^{72}$ Islamic finance products include mudaraba and musharaka (different forms of partnership), ijara (leasing), istisnaa (manufacturing) and murābaḥa. See generally Mahmoud Amin elGamal, A Basic Guide to Contemporary Islamic Banking and Finance (Rice University, 2000).
} 
most controversy. In Pakistan, murābaḥa totalled 87 per cent of total financing, in Dubai Islamic Bank it constituted 82 per cent and in the Islamic Development Bank in Jeddah, Saudi Arabia, murābaha totalled 73 per cent. ${ }^{73}$ Saeed highlights several reasons for the popularity of murābaha. First, murābaha is a short term mechanism in comparison to other PLS products. Second, it allows banks to receive a return which is often comparable to the return received by interest-based banks with which the Islamic banks are competing; and third, it avoids the uncertainty associated with PLS products. ${ }^{74}$ Saeed's second reason goes to the heart of the issues considered in this article. While muräbaha products may be popular in the modern Islamic finance industry, there is also a lot of controversy surrounding them. Muräbaḥa will now be discussed in detail.

\section{MURĀBAHA}

Muräbaha comes from the Arabic word 'ribh' which means gain, profit or addition derived from the sale of a commodity on a cost-plus basis, including a profit margin. ${ }^{75}$ The current Islamic banking and finance industry also refers to murābaha as 'cost-plus profit financing' which often involves an Islamic finance institution (IFI) selling a commodity to a purchaser at a cost plus a mark-up profit rate. Instead of sharing profits and losses, the IFI acts as a financial intermediary. ${ }^{76}$ As will be seen below, certain basic requirements must be met before a murābaha product is considered Sharī' $a$-compliant. These include that the buyer has knowledge of the costs and profit margin; that the subject of the sale is goods or commodities against money; that the subject of the sale is in the possession of the seller; and, that the payment is deferred. ${ }^{77}$ Classic Hanafi jurist, Al-Marghinani (d 1197) defines murābaha as 'the sale of anything for the price at which it was purchased by the seller and an addition of a fixed sum by way of profit'. ${ }^{78}$ The Maliki and Shafi'i schools of thought find murābaḥa sale lawful but have not referenced hadìth to back up their legal conclusion. This has led critics such as Al-Kaff to argue that murābaha was not a sale known to the Prophet and his companions and is therefore not Sharī $a$ compliant. ${ }^{79}$ On the other hand Maliki mentioned murābaha in the Al-

\footnotetext{
${ }^{73}$ Figures from the 1980s: Saeed, 'Islamic Banking in Practice: A Critical Look at the Murabaha Financing Mechanism', above n 4, 61.

${ }^{74}$ Saeed, Islamic Banking and Interest, above n 20, 78.

${ }^{75}$ Ayub, above n 27, 215.

${ }^{76}$ Nabil A Saleh, Unlawful Gain and Legitimate Profit in Islamic Law (Cambridge, 1986) 94.

${ }^{77}$ Saeed, Islamic Banking and Interest, above n 20, 77.

${ }^{78}$ Ayub, above n 27, 216.

${ }^{79}$ Al Kaff, 'Does Islam Assign Any Value’ (Islamic Research Academy, 1986) cited in Saeed, Islamic Banking and Interest, above n 20, 76.
} 
Mu'watta - a book on the traditions of the Prophet. ${ }^{80}$ Examining the practices of the people of Medina, Maliki noted that it was known that people who purchased cloth in a town would sell it in another town on an agreed profit basis. ${ }^{81}$ Shafi'i also agreed that murābaha was a lawful transaction, and Marghinani justified murābaha on the grounds that it protected customers who lacked expertise in trade as there is a mutually agreed upon profit margin. ${ }^{82}$

Regardless of the differences of opinion, cost plus profit financing had by the 1980s become one of the most popular forms of Islamic financing with over 75 per cent of Islamic finance products being financed through this mode of financing. ${ }^{83}$ As we will see below, certain basic principles must usually be met before a murābaha product is considered Shariah-compliant. A basic cost plus profit murābaha sale structure can be explained as follows:

Figure A

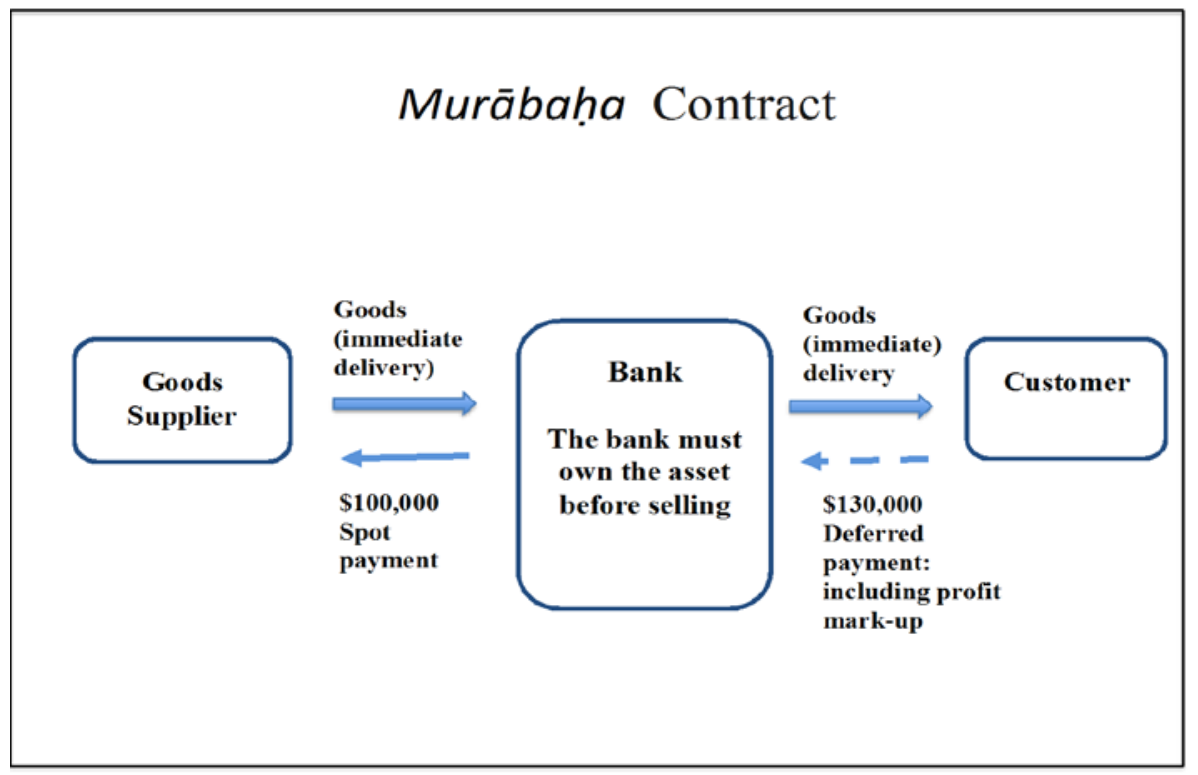

\footnotetext{
80 Saeed, Islamic Banking and Interest, above n 20, 78.

81 Ibid.

${ }^{82}$ Ayub, above n 27, 216.

${ }^{83}$ Saeed, 'Islamic Banking in Practice: A Critical Look at the Murabahah Financing Mechanism', above n 4, 61 .
} 
As Figure A shows, the following steps need to take place for a murābaha transaction to be valid. These are:

1) The customer approaches the bank and requests the purchase of goods.

2) The customer and the bank sign a contract whereby the bank promises to sell and the customer promises to buy the commodity for the agreed cost plus profit (in Figure A, corresponding respectively to $\$ 100000+$ $\$ 30$ 000). The bank appoints an agent or the goods supplier to purchase the item. The customer may decide to act as an agent of the bank. If so, an agreement of agency is signed between the parties involved in the underlying contract, based on a wakalah contract to acquire the asset from the supplier. An agency agreement is not needed where the bank purchases the commodity directly from the supplier.

3) The bank purchases the commodity from the goods' supplier.

4) The bank pays the goods' supplier the cost of the commodity (in Figure A, $\$ 100$ 000).

5) If the customer is the agent, he/she takes delivery of the item on behalf of the bank as its agent.

6) The customer offers to purchase the commodity and once the bank accepts the offer, the title over the commodity transfers to the customer.

7) The customer pays the cost plus profit on a deferred basis. ${ }^{84}$

Usmani ${ }^{85}$ notes that it is extremely important for the bank to bear an element of risk while the commodity is in its possession. In his opinion, this is one of the characteristics that essentially distinguishes murābaha from an interest-based transaction. ${ }^{86}$

Two sale contracts govern the murābaha transaction: one between the bank and the customer, and one between the bank and the good supplier.

\footnotetext{
${ }^{84}$ Ayub, above n 27, 225-6.

${ }^{85}$ Mufti Muhammad Taqi Usmani is a scholar of Islamic finance and a Sharī $a$ expert. See Mufti Muhammad Taqi Usmani, Profile (2015) Mufti Muhammad Taqi Usmani $<$ http://muftitaqiusmani.com/en/?page_id=11333>.

${ }^{86}$ Ayub, above n 27, 225-6.
} 
In practice, a bank usually appoints an agent (wakil) to acquire the assets/goods on the bank's behalf after the customer has identified the assets. ${ }^{87}$ The supplier of the goods may also act as the bank's agent and deliver the asset directly to the customer. When the customer accepts the offer and agrees to pay the bank on a specified date, the agency relationship is lawfully terminated. ${ }^{88}$ However, a murābaha transaction through an agency agreement risks being Sharī $a$ noncompliant, as the bank may not have constructive possession of the product before the customer receives it. Usmani notes:

The best way to effect murabahah is that the financier himself purchases the commodity directly from the supplier and after taking its delivery sells it to the client on murabahah basis. Making the client agent to purchase on behalf of the financier renders the arrangement dubious. For this very reason some Shari 'ah Boards have forbidden this technique, except in cases where direct purchase is not possible at all. Therefore, the agency concept should be avoided as far as possible. ${ }^{89}$

For a murābaha product to be distinguished from an interest-based product, it is important that the commodity being sold is in the constructive possession and ownership of the bank at the time of the sale. ${ }^{90}$ Constructive 'possession' means that the bank has rights, liabilities and risks in respect of the commodity, which implies that the bank must have ownership of the commodity. ${ }^{91}$ It also means that the subject of sale must exist at the time of sale. The fact that the bank bears the risk of default and delinquency while the goods are in its actual or constructive possession is one of the elements that qualifies the murābaha mode of financing as $\operatorname{Sharī~}^{-} a$-compliant. ${ }^{92}$

Shari ' $a$ compliance is fulfilled by ensuring that the subject of sale is not a commodity forbidden under $\operatorname{Sharī}^{-} a$, the commodity is sold through a valid contract, and the price and payment plan known and fixed at the time the contract is signed, thereby ensuring that gharar, or uncertainty, is avoided; the profit/mark-up is also determined and expressed prior to the purchase and often benchmarked according to market interest rates, such as LIBOR; ${ }^{93}$ the seller

\footnotetext{
87 Abradat Kamalpour et al, 'Murabaha financing' (Briefing, Ashurst, January 2009) 1-3 $<$ www.ashurst.com/doc.aspx?id_Content=4298>.

${ }^{88}$ Ibid.

${ }^{89}$ Muhammad Taqi Usmani, An Introduction to Islamic Finance (Kluwer Law International, 2002) 67.

${ }^{90}$ Mohammed Obaidullah, Islamic Financial Services (King Abdulaziz University Press, 2005) 72.

${ }^{91}$ Ibid.

${ }^{92}$ Kamalpour et al, above n 87.

${ }^{93}$ Ibid.
} 
discloses any defects of the commodity prior to the sale; and, the sale involves the full transfer of the legal rights over the commodity. ${ }^{94}$

\section{TAX CONSIDERATIONS}

\section{A Implementation of Murābaha in Australia}

Many argue that murābaha contracts in Australia are very similar to conventional interest-based contracts because both are used to finance mortgages. However, while the economic substance of murābaha financing is similar to a fixed interest loan backed by a mortgage, the form is different because murābaha financing does not include interest. Taxation of the product will depend on whether it is the form or the substance of the murābaha transaction that is focused on, as will be seen below. Apart from providing a Sharī 'a-compliant method of purchasing a house, the murābaha form of financing is significant because Australia is a net capital importer and tawarruq or commodity murābaḥa, known more commonly as 'interbank finance', is used by Australian financiers to access offshore capital. ${ }^{95}$ A tawarruq contract differs from a murābaha contract because the former is used to generate cash and is therefore known as a 'cash finance sale'. ${ }^{96}$ It consists of a foreign financier, a resident investment agency, a resident client (bank or financier), a commodity supplier and a commodity buyer. A tawarruq contract involves the following transactions: ${ }^{97}$

1) The foreign financier signs an agency agreement with an Australian investment agency (AIA). The AIA will act as the foreign financier's agent.

2) The commodity supplier provides the AIA with commodities and immediate settlement and payment.

3) The AIA sells the commodity to the client (bank or financier) at $\$ \mathrm{X}$ plus profit mark-up (sale price) on an immediate settlement but deferred payment basis. The net result is that while the client owns the

\footnotetext{
${ }^{94}$ Ibid.

${ }^{95}$ Discussion Paper (2010), above n 1, 32.

${ }^{96}$ Ibid 8.

${ }^{97}$ Ibid.
} 
commodity, the client owes money to the foreign financier because the AIA acted as an agent for the foreign financier.

4) The client sells the commodity to the commodity buyer for $\$ X$ on the spot settlement and payment basis. The client has now generated cash.

5) The client pays the sale price to the AIA at the end of the agreement and all the proceeds are distributed to the foreign financier. ${ }^{98}$

The taxation implications arising from the implementation of this transaction was one matter considered by the Board in its Discussion Paper.

\section{B The Board's Discussion Paper}

The Board's Discussion Paper considers various Islamic finance products including the basic cost-plus-profit murābaha product and interbank financing which are the focus of this article. As shown below, it is clear from the Board's analysis of two case studies and the submissions of various IFIs and related groups that mark-up should be treated as interest for taxation law purposes, in order for murābaha to be treated equally with conventional products. While the taxation implications of murābaha products will not be analysed here in detail, the way in which the Board treats a cost-plus-profit sale similar to a conventional fixed interest mortgage - in terms of its structure and the deductibility of the profit mark-up — will be briefly summarised. ${ }^{99}$

\section{Cost Plus Profit Sale and a Conventional Fixed Interest Mortgage}

\section{Structure}

The structure of a basic murābaha transaction has been described above. As shown, this arrangement may be used to finance the purchase of a property and is equivalent to a conventional fixed interest mortgage. The difference is that in a conventional mortgage the borrower repays the cost plus interest to the lender and the lender has security over the borrower's property in the event of a default. By contrast, an Islamic Financier owns the property outright and the borrower repays the cost plus profit on a deferred payment plan. The additional

\footnotetext{
${ }^{98}$ Ibid.

${ }^{99}$ The Board also treats Islamic interbank finance similarly to a conventional debt instrument. Further, it is important to characterise profit mark-up as interest for interest withholding tax (IWT) purposes in order to ensure equality.
} 
profit mark-up that an Islamic borrower repays is treated as equivalent to the interest that a conventional borrower repays and therefore, the net cost is the same. It is clear from the Board's Discussion Paper that an Islamic mortgage should be treated according to its economic substance and that from this perspective, profit mark-up is equivalent to interest. ${ }^{100}$ The Board argues, therefore, that existing taxation frameworks that apply to a conventional mortgage should apply to murābaha. ${ }^{101}$

\section{Deductibility of Profit Mark-Up}

When it comes to deductibility of profit mark-up, the Discussion Paper notes that in order for murābaha to be treated equally with conventional products, the profit mark-up should be deductible. ${ }^{102}$ This will mean either deducting the mark-up under section 8-1 of the Income Tax Assessment Act 1997 (Cth) ('ITAA 1997') by characterising mark-up as interest, or doing so under section 25-85 of the ITAA 1997, under which a return on a debt interest may be deducted. In order to fall under this section, the murābaha arrangement must be a 'debt interest' under Division 974 of the ITAA 1997. ${ }^{103}$

\section{Islamic Interbank Finance (IIF) and Conventional Debt Instrument (CDI)}

The structure of Islamic interbank finance is described above. The Board is consistent in its view that the economic substance of these arrangements should be analysed, as opposed to their form. ${ }^{104}$ The Board argues that for taxation purposes the economic substance of an IIF should be equivalent to a conventional debt instrument issued by a resident Client. ${ }^{105}$ Further, the sale price of an IIF arrangement should be treated as equivalent to the face value of the CDI, and the profit mark-up in an IIF should be equivalent to a return on the CDI.

If the substance-based approach is taken, the return on the CDI will be treated as interest under interest withholding tax provisions for non-resident financiers. ${ }^{106}$ Therefore, the profit mark-up under IIF will also be treated as

\footnotetext{
${ }^{100}$ Discussion Paper (2010), above n 1, 27-9.

${ }^{101}$ Ibid 30-1.

102 Ibid 29-30.

103 Ibid.

104 Ibid 34.

${ }^{105}$ Ibid.

${ }^{106}$ Ibid 34-5.
} 
interest for IWT purposes because of the expanded definition of interest under section 128A (1AB) of the ITAA 1936:

interest includes an amount, other than an amount referred to in subsection 26C(1):

(a) that is in the nature of interest; or

(b) to the extent that it could reasonably be regarded as having been converted into a form that is in substitution for interest.

Arguably, the 'profit mark-up' is akin to the nature of interest because, if one views the economic substance of murābaha, the profit mark-up is the increased price that one pays because of delayed payments. ${ }^{107}$ Commenting on section 128(1AB), Buchanan states, 'as far as I'm aware (not being a Sharī'a scholar) this interpretation would not, of itself, cause the mark-up to be considered riba ' $^{108}$ However, his comment on treating mark-up as interest under s 25-85 and s 128(1AB) ITAA 1936 provides no reason why mark-up will not be considered ribā for Muslims, and the subject is obviously controversial despite Buchanan's claim. The impact for Muslims of treating mark-up as if it were interest will be discussed in detail below.

\section{E IWT Exemption}

One of the points highlighted in the submissions following the Discussion Paper is that the Double Taxation Agreement (DTA) under the International Tax Agreements Act 1953 (Cth) (ITAA 1953) may allow withholding tax to be eliminated if the interest is paid to an unrelated financial institution overseas. ${ }^{109}$

The major issue in the case of IIF, however, is that Australia does not have DTAs with many Islamic countries. This means that the profit mark-up may be taxed even where the non-resident does not have a permanent establishment in Australia. ${ }^{110}$ If an IWT exemption is not applied, the resident agent will withhold IWT from the interest it receives because the non-resident financier

\footnotetext{
107 Richard Buchanan, 'Islamic Finance: The Path to Tax Neutrality' (Paper presented at the Financial Services Taxation Conference, Sanctuary Cove, Queensland, 11-12 February 2010) 11.

108 Ibid.

${ }^{109}$ Ibid 12; Blake Dawson, Submission to the Australian Government, Board of Taxation, Review of the Taxation Treatment of Islamic Finance (2010) 17 December 2010, 5-6; MCCA Limited, Submission to the Australian Government, Board of Taxation, Review of the Taxation Treatment of Islamic Finance (2010) 3.

${ }^{110}$ Buchanan, above n 107, 11.
} 
will eventually become entitled to receive the interest under Section 12-250 in Schedule 1 of the Taxation Administration Act 1953 (Cth). ${ }^{111}$

If the profit mark-up is not treated as interest, the mark-up may be treated as an 'income gain', which results in unequal tax treatment. If the client is a nonresident of Australia and a resident of a country with which Australia does not have a DTA, the next question to determine will be whether the gain or profit took place in Australia. ${ }^{112}$ If it did take place in Australia, that is, if Australia was where the contract was signed and the purchase entered into, then the gain would be subject to Australian tax at a rate applicable to a non-resident client; for a corporation this is 30 per cent. ${ }^{113}$ Norman and Challoner note that this would 'be an unfavourable outcome as compared to the margin in a commodity murabahah being treated as "interest"'. ${ }^{114}$

\section{F Taxation of Financial Arrangements (TOFA) Tax Timing Rules}

The Taxation of Financial Arrangements tax-timing rules ${ }^{115}$ were introduced as a reform to the previous taxation system where a 'form over substance' approach was used to classify financial arrangements. The explanatory memorandum to the Tax Laws Amendment (Taxation of Financial Arrangements) Act 2008 (Cth) notes that the previous form over substance approach: 'has resulted in inconsistencies in the tax treatment of transactions with similar economic substance which has impeded commercial decisionmaking, created difficulties in addressing financial innovation, and facilitated tax deferral and tax arbitrage'. ${ }^{116}$ It is for this reason that TOFA tax-timing rules do not refer to ‘interest' but to 'gains and losses'.

For the resident financier, interest under a conventional mortgage is viewed as a gain from a financial arrangement using the accruals method. A similar treatment of 'profit mark-up' is proposed by the Board in order to ensure equal treatment between murābaha and a conventional fixed interest mortgage. ${ }^{117}$ Treating 'interest' under a conventional fixed interest mortgage and the 'profit

\footnotetext{
${ }^{111}$ Ibid.

112 Peter Norman and John Challoner, 'Shariah Compliant Financing in Australia' (2010) 13(4) The Tax Specialist 186, 191.

${ }^{113}$ Ibid.

114 Ibid.

115 Tax-timing is the term used when income is recognised and expenses are deductible for tax purposes.

${ }^{116}$ Explanatory Memorandum, Tax Laws Amendment (Taxation of Financial Arrangements) Bill 2008.

${ }^{117}$ Discussion Paper (2010), above n 1, 15-17.
} 
mark-up' under murābaha equally is in line with the TOFA practice of taking a substantive rather than a form based approach to financial arrangements. The obvious conclusion that one reaches is that, in substance, a murābaha home loan is no different to a conventional fixed interest mortgage.

This brief summary shows how profit mark-up is treated as interest for taxation purposes in Australia. The next section will analyse the present discourse on the treatment of murābaha.

\section{Present Discourse on the Treatment of MURĀBAHA}

\section{A Implications of Treating Mark-Up as Interest - Different Perspectives}

As mentioned, the Board proposes that mark-up be treated as interest for taxation purposes in order to ensure that Islamic finance products are treated equally with conventional products. Two matters in particular arise out of the treatment of mark-up as interest: whether murābaha will be viewed as Sharī $a$ compliant when mark-up is treated as if it were interest, and, if not, whether this could cause Australia to become less attractive for international investors. These two questions will be addressed by a consideration of the implications of treating mark-up as interest from the perspectives of Australian financial institutions and related bodies on the one hand and United Kingdom bodies on the other.

\section{B Australian Financial Institutions (AFIs) and Related Groups}

As shown above, the Board discusses treating mark up as interest for tax purposes. The Board does not view this as being problematic. It may be argued, however, that the Australian financial institutions and related groups responding to the Discussion Paper are not Islamic institutions and strict Sharī $a$ compliance is not a significant issue for them. However, $\operatorname{Sharī~}^{\prime} a$ compliance should be an issue for AFIs and related groups to the extent that their international portfolio and the authenticity of the Sharī $a$-compliant products being offered can be affected.

Furthermore, unlike the United Kingdom, Australia does not have an Islamic bank but rather co-operatives such as the Muslim Community Cooperative Australia Ltd (MCCA). The MCCA submission indicates agreement with the method proposed by the Board, but expresses worry about the impact that the term 'interest' may have on the community. The MCCA justifies its submission 
by arguing that the returns in a murābaha product, are not 'interest' in the ordinary sense of the term. ${ }^{118}$ However, the MCCA submissions does not define 'interest' clearly. One can conclude that, while the MCCA is concerned about the impact that the taxation of muräbaha will have on the community, it is not opposed to the taxation process but rather wants to change the 'name' as opposed to the 'form' of the taxation terminology used. The MCCA submission also expresses agreement that, ' $[\mathrm{t}] \mathrm{o}$ create a level playing field for Islamic finance, business costs, even though they are called profits, should be accommodated under the general deductibility of section 8-1 of the ITAA 1997.' ${ }^{119}$ Therefore, the MCCA seems to be supporting the treatment of profit mark-up as interest, despite its proposition that the term 'interest' should not be used.

One can also argue that it takes a contextual approach to the definition of riba and does not characterise interest in the murābaha product as riba $\bar{a}$. For the MCCA, profit mark-up and returns on Islamic products are Sharī $a$-compliant. This is made clear in paragraph 12 of the MCCA's submission:

For Islamic finance products based on cost plus profit sales and other methods, the word 'interest' should not be used in the legislation. Rather the terms like profit, rent or fee, as appropriate, should be used to identify relevant returns. Returns paid for Shariah compliant products are generally derived on the basis of trading profits, rental payments or management fees. By definition, these returns are not interest in an ordinary sense of the term. Hence, we propose to identify them as they are derived as profits, rentals or fees. This will avoid any potential controversies in relation to the Shariah concept of finance. ${ }^{120}$

The Board does not discuss in detail the fact that the word 'interest' is used in the legislation. Rather, it focuses on the substance of the product and treating Islamic finance products equally to conventional products. This approach is followed by a law firm, Blake Dawson, which notes in its submission

that based on the case law, the better view is that the profit component could be regarded as interest for the purposes of the IWT provisions. However, in the context of Shariah-compliant products such as the BBA ${ }^{121}$, there will be a number of contractual arrangements between the Client and the nonresident financier to reflect the different legal relationships required to ensure

\footnotetext{
118 MCCA Limited, above n 109, 4.

119 Ibid 1.

${ }^{120}$ Ibid 4.

${ }^{121} \mathrm{BBA}$ or Al-Bai' Bithaman Ajil is a term typically used in Malaysia and an alternative name for murābaha.
} 
that the profit component derived by the non-resident financier is not considered riba. Any conditionality between the contractual arrangements could together create uncertainty as to whether the profit component does in fact satisfy the definition of interest in section 128A(1AB). However, if the definition of interest was amended to explicitly include the profit component, this should provide sufficient certainty. ${ }^{122}$

Blake Dawson does not discuss the problem of interest from a social perspective, but from a legal standpoint. Again, agreeing with the Board, the Blake Dawson submission notes that it is important for the profit component to be treated as interest for the purposes of tax. In the future, the Board will need to address Blake Dawson's proposal that in order ensure certainty, the profit component must fit the definition of interest.

Ernst \& Young take a similar position to Blake Dawson submitting that profit be treated as interest for taxation purposes, but further submit that amending the legislation would be complex and costly and would add to the already huge volume of taxation law in Australia. Instead, Ernst \& Young propose an approach that allows the current legislation to govern Islamic finance products by treating murābaha as equivalent to an interest-bearing loan. ${ }^{123}$

The submission of the international law firm Norton Rose, proposed that legislative amendments be made, but recommended that the amendments not be couched in religious terms so that they are not seen as discriminatory and favouring a particular religion. Freudenberg and Nathie from Griffith University discuss the constitutional implications of introducing faith-based legislation in detail in their submission. ${ }^{124}$ They note the tension between section 116 of the Australian Constitution providing for religious freedom, and section 51, which provides the Commonwealth with the power to tax. Freudenberg and Nathie refer to the case of Halliday $v$ The Commonwealth of Australia $^{125}$ and the Fairfax decision ${ }^{126}$ to argue that taxation power is broad enough to cater for Islamic finance without resulting in discrimination or being in conflict with secular taxation law. ${ }^{127}$

\footnotetext{
122 Blake Dawson, above n 109, 3.

${ }^{123}$ Ernst \& Young, Submission to the Australian Government, Board of Taxation, Review of the Taxation Treatment of Islamic Finance (2010) 17 December 2010, 2-3.

${ }^{124}$ For a more detailed discussion see: Dr Brett Freudenberg and Dr Mahmood Nathie, Submission to the Australian Government, Board of Taxation, Review of the Taxation Treatment of Islamic Finance (2010) 17 December 2010.

125 [2000] FCA 950.

${ }^{126}$ Fairfax $v$ FC of $T$ (1965) 114 CLR 1.

${ }^{127}$ Freudenberg and Nathie, above n 124, 10-15.
} 
However, Norton Rose proposes the approach taken by the United Kingdom government:

For example, section 47 of the UK's Finance Act 2005 was introduced to address tax issues associated with commodity Murabaha transactions ...The approach of this provision in the UK legislation is to describe, in fairly simple terms, the elements of the transaction, to look at whether the difference between the sale price and the purchase price equates, in substance, to the return on an investment of money at interest and to then treat that margin as the 'alternative finance return'. The 'alternative finance return' is then treated as interest for all United Kingdom tax purposes. ${ }^{128}$

From the perspective of the MCCA, this approach would have a less controversial impact on the community than the idea posited by the Australian Board of Taxation, and from the perspective of Norton Rose it would be a simple approach that looks at the economic substance of the product as opposed to its form, and allows Western and Islamic products to be treated equally for taxation purposes. This approach, however, assumes that simply changing the term 'interest' will appease the Muslim community.

A quick fix response of changing the terminology to 'alternative finance return', or, as proposed by the MCCA, 'financier withholding tax' as opposed to the term 'interest withholding tax', does not deal with the issue of whether the profit or return being discussed may be viewed as interest under Sharī' $a$ regardless of how it is treated under Australian law. The submissions seem to be based on the assumption that the profit mark-up in the murābaha product is allowed under Sharī $a$ and is not of a controversial nature. For example, in the Taxation Institute and Australian Financial Markets Association joint submission, the discussion of IWT simply notes that the profit component in a tawarruq transaction should fall under the definition of interest under section $128(1 \mathrm{AB})$ of the ITAA $1936 .{ }^{129}$

Two submissions deal with the impact of Islamic finance products on Australian society. The first submission is by David Clark, a member of the NSW Legislative Council representing the Liberal Party of Australia, and a strong advocate of 'Christian values'. ${ }^{130}$ The other is by Vickie Janson, the vice-

\footnotetext{
${ }^{128}$ Norton Rose Australia, Submission to the Australian Government, Board of Taxation, Review of the Taxation Treatment of Islamic Finance (2010) 17 December 2010, 14-15.

${ }^{129}$ The Taxation Institute of Australia and Australian Financial Markets Association, Submission to the Australian Government, Board of Taxation, Review of the Taxation Treatment of Islamic Finance (2010) 18 January 2011, 18-20.

${ }^{130}$ ABC Radio National, 'David Clark’, Sunday Profile, 18 September 2005 (Monica Attard and David Clark) <http://www.abc.net.au/sundayprofile/stories/s1461663.htm>.
} 
president of Q Society, a group that opposes what it claims to be the 'Islamisation' of Australia. ${ }^{131}$ Clark notes in his submission:

the Board should not be relying on the 'Islamic economic system' as a basis of the review. This is not the system that the Islamic finance operates in and is partly why Islamic financial products must replicate conventional products. As Islamic finance operates in a conventional system and Islamic finance principles adapt to accommodate this system, in substance Islamic finance principles are conventional principles. Thus, the assumption that Islamic finance products are based on Islamic finance principles, operating in an Islamic economic system has no worth in a practical exercise to determine the appropriate tax treatment of Islamic finance products. ${ }^{132}$

This comment is flawed in that, as shown above, the Board does not rely on the Islamic economic system as a basis of its review. It is interesting to note, nonetheless, that Clark's submission, unlike the other submissions, addresses the issue of Islamic finance principles being very similar to conventional principles. However, he discusses this in the context of pointing out inherent problems with Islamic finance products and, in sum, of asserting that the Islamic finance industry will 'jeopardise the integrity of the Australian financial services industry'. ${ }^{133}$ Janson takes a similar but more confronting approach to the Discussion Paper:

I would strongly recommend that the government reassess this commitment to sharia finance with its connections to Islamic groups, it’s [sic] theological foundations and it's [sic] undermining of both western values and economy... It appears support for sharia finance is support for Islamic ideologies rather than the moderates who utilise conventional banking. ${ }^{134}$

Janson also claims that the leaders in the Islamic finance industry, such as Usmani, have jihadist views. ${ }^{135}$ She is more concerned about the impact that Shari' ' $a$ products will have on 'Australian values'136 than with the provision of space for Islamic finance products in Australia. Although this view is not shared

${ }^{131}$ Q Society of Australia Inc, Why We Oppose Islam (2013) <http://www.qsociety.org.au/ opposing_islam.htm>.

132 David Clark, Submission to the Australian Government, Board of Taxation, Review of the Taxation Treatment of Islamic Finance (2010) 15 December 2010, 2 [3.1(d)].

133 Ibid 6 [7.1].

${ }^{134}$ Vickie Janson, Submission to the Australian Government, Board of Taxation, Review of the Taxation Treatment of Islamic Finance (2010) 30 November 2010, 5.

135 Ibid 1.

136 The concept of 'Australian values' is not discussed in detail in this article. More information on Vickie Janson's concept of how 'Islamic values' are incompatible with 'Australian values' can be found in her book Vickie Janson, Ideological Jihad (Castle Publishing Services, 2009). 
by other AFIs, law firms and/or financial institutions, it is a view held by a number of Australians who pit Islamic values against Western values and fear the influence of the former. For example, Liberal Party Senator Bernardi shares Clark's and Janson's views, and is opposed to the introduction of Shari 'a banking in Australia because, in his view, Islamic law is incompatible with Australia's 'western values' ${ }^{137}$ In an interview with the ABC, Senator Bernardi said:

Sharia finance is one aspect of Sharia or Islamic law and I reject it entirely. We shouldn't be changing our legal system or our legal framework to accommodate a system of laws that is wholly incompatible with Western values... And Sharia is not just about commercial transactions, it indulges an aspect of every part of people's lives ... so it's like a ball of string that once you start tugging at it, the entire ball becomes unravelled and that's something I don’t want to see happen in this country. ${ }^{138}$

In an attempt to counter such views, the Malaysian law firm, Zaid Ibrahim \& Co, which has recently set up offices in Sydney and Melbourne, released a publication titled 'Demystifying Islamic Finance', in which it identifies what it sees as the 15 most frequent misconceptions about Islamic finance in the western world. ${ }^{139}$ Clark's argument that Islamic finance products are very similar to conventional products is addressed under 'Misconception 3' 'Replica of Conventional Finance'. Zaid Ibrahim \& Co note: '.. the fact remains that Islamic finance are [sic] governed by some fundamental principles that are contrary to conventional finance, such as prohibitions against riba (usury/interest), maisir (betting/gambling) and gharar (dubious ambiguity). ${ }^{140}$ Furthermore, under 'Misconception 15': 'To replace conventional system, aimed towards Islam's world domination', the publication addresses the argument of Janson and Senator Bernardi that Islamic finance is undermining the theological underpinnings of Australian society. Under this heading the firm notes: 'How would this be possible when the whole Islamic finance system

\footnotetext{
${ }^{137}$ AAP, 'Liberal Senator Cory Bernardi's Bid to Curb Sharia Banking Dealt Blow by Colleague George Brandis', The Australian (online), 2 November $2010<$ http://www.the australian.com.au/national-affairs/politics-news/liberal-senator-cory-bernardis-bid-to-curbsharia-banking-dealt-blow-by-colleague-george-brandis/story-fn59nqld-1225946697055>.

${ }^{138}$ ABC National Radio, 'Liberal Senator Wants to Stop Sharia Banking Expansion', AM, 2 November 2010 (Tony Eastley and Cory Bernardi) <http://www.abc.net.au/am/content/ 2010/s3054541.htm>.

139 Zaid Ibrahim \& Co, 'Demystifying Islamic Finance: Correcting Misconceptions, Advancing Value Propositions’ (Booklet, Zaid Ibrahim \& Co) <http://wasil.org.pk/Knowledge-Center/ Demystifying-Islamic-Finance-soft-copy.pdf $>$.

${ }^{140}$ Ibid 9.
} 
accounts for less than $1 \%$ of the global financial system, and Muslim nations remain largely the poorest and under-developed?' ${ }^{141}$

Crescent Investments Australasia (CIA) also take a very different approach to Janson and Clark. ${ }^{142}$ Crescent Investment's submission claims that there are murābaha products that are Shari ${ }^{-} a$-compliant and agrees with the way in which the Board proposes to tax the products. CIA also notes that it will not deal in debt-based products but believes that the tax implications have been covered adequately. ${ }^{143}$

Similarly, Freudenberg and Nathie from Griffith University agree that the way in which the Board proposes to tax murābaha will ensure equality of treatment between conventional and Islamic finance products, and encourage alternative forms of financing. ${ }^{144}$ However, they do note that the introduction of Islamic finance both in Australia and the UK is 'based on "access to good financial services" and not religion'. ${ }^{145}$ This is an important point because, in contrast to the views of Clark and Janson, the issue for AFIs and related bodies is not religion, but economic development. On this view, Australia benefits from the introduction of Islamic finance products to its financial system as this opens doors to greater investment of capital from overseas and this in turn paves the way for greater economic prosperity and development.

None of the submissions to the Discussion Paper have discussed in detail the religious controversies involved in treating mark-up as interest. As mentioned, if anything, the taxation treatment of mark-up is simply assumed to be Sharī' $a$ compliant. Islamic banking in Australia is only in its infancy. Apart from the submissions discussed above and available for public view, no public submissions by Shari 'a scholars or members of the Muslim community in Australia appear on the Board's website. One can only assume that the Australian Muslim community either accepts the Board's view of how Sharī $a$ compliant products should be taxed, or that Islamic finance is not developed enough in Australia to spur debate. This is in contrast to the position in the UK, where Islamic finance has spurred extensive debate.

\footnotetext{
${ }^{141}$ Ibid 22.

142 Crescent Investments Australasia, Submission to the Australian Government, Board of Taxation, Review of the Taxation Treatment of Islamic Finance (2010).

143 Ibid.

${ }^{144}$ Freudenberg and Nathie, above n 124, 2.

${ }^{145}$ Ibid 15.
} 


\section{Financial Institutions in the United Kingdom}

The United Kingdom has paved the way for other Western countries to develop and support Islamic finance. The statistics highlighted in a publication by TheCityUK in 2013 noted that the United Kingdom had a total of US\$19 billion in Shar $\bar{\imath}^{-} a$-compliant financial assets. ${ }^{146}$ The assets were largely held by HSBC Amanah, which is the Islamic financial services division of the HSBC Group that provides Islamic financial services across various countries. According to this publication, not only did the UK financial system contain the most Islamic financial assets in the West; it was placed ninth globally and ahead of major Muslim-majority countries such as Pakistan, Turkey and Indonesia. ${ }^{147}$ This may be because the UK has a large Muslim population of approximately 2.9 million. ${ }^{148}$

With the support of the Bank of England and the Financial Services Authority (FSA) in the UK, several legislative amendments ${ }^{149}$ were introduced in 2003 to achieve similar objectives to those that the Board proposes for Australia in its Discussion Paper. The reaction by UK financial institutions and related bodies was very similar to that of Australian bodies, the only difference being that there was more debate and reaction from the UK Muslim community, as discussed further below.

As noted in the Financial Services Authority (FSA) publication on Islamic Finance in the UK, the UK has been involved in the Islamic finance industry for 30 years and international institutions such as Citi, Deutsche and HSBC have been established in the Middle East and South East Asia. ${ }^{150}$ This has meant that these banks have gained knowledge of the economic system in the region, including Islamic banking practices. For this reason, the banks have been quick

\footnotetext{
${ }^{146}$ Marko Maslakovic, 'UK the Leading Western Centre for Islamic Finance' (Report, Financial Markets Series, TheCityUK, October 2013) 3 <http://www.thecityuk.com/research/ our-work/reports-list/islamic-finance-2013>.

${ }^{147}$ Ibid 5.

${ }^{148}$ Pew Research Centre, 5 Facts about the Muslim population in Europe (17 November 2015) $<$ http://www.pewresearch.org/fact-tank/2015/11/17/5-facts-about-the-muslim-population-ineurope/>.

149 The legislative amendments in the UK consisted of reforming the income tax rules to accommodate alternative finance arrangements; reforming the stamp duty land tax to remove double taxation; explaining how to determine 'finance cost' and, in 2007, introducing legislative reforms to facilitate the issue of sukuk or Islamic bonds to ensure that the same tax treatment would apply. See Discussion Paper (2010), above n 1, 467.

${ }^{150}$ Michael Ainley et al, 'Islamic Finance in the UK: Regulation and Challenges' (Financial Services Authority, Discussion Paper, November 2007) $7<$ http://media4.efinancialnews.com/ share/media/downloads/2007/11/2349281881.pdf > .
} 
to offer Islamic products internationally and locally in London. ${ }^{151}$ This has benefited both international financial institutions and UK-based institutions. For example, in 2007 Kuwait's largest holding company, Investment Dar and Adeem Investment Co bought a stake in Aston Martin. Adeem is an investment and asset management company that only invests in Shari $a$-compliant products. Sharia-complaint financing was used in the purchase of Aston Martin. ${ }^{152}$ In a speech in September 1995, Lord Edward George, Governor of the Bank of England, noted the 'growing importance of Islamic banking in the Muslim world and its emergence on the international stage as well as the need to put Islamic banking in the context of London's tradition of competitive innovation.' ${ }^{153}$ In September 2003, Sir Howard Davies, then Chairman of the FSA, gave a speech in Bahrain saying that the UK had 'a clear economic interest in trying to ensure that the conditions for a flourishing Islamic market are in place in London' and that it would be 'good for Muslim consumers, good for innovations and diversity in our markets and good for London as an international financial centre'. ${ }^{154}$ Thus, discussion on Islamic finance products has existed in the UK since the 1990s and legislative amendments were made in 2003 and 2007, ${ }^{155}$ whereas Islamic finance products have only very recently emerged in Australia and legislative changes are yet to be made.

Islamic finance has been so welcomed by financial institutions in the UK that it has resulted in the following:

- The UK is currently the leading Western country for Islamic finance with US $\$ 19$ billion of reported assets;

- More than 20 banks with Sharĩ $a$ windows, six of which are fully Sharī' a compliant;

- 25 law firms with expertise in Islamic finance;

- Advisory services on Islamic finance in the four major professional services firms and ten universities and business schools in the UK;

- $\quad$ The UK issued Sukuk (Islamic bond) valued at $£ 200$ million, maturing on 22 July 2019 and sold to investors in the UK and globally. The

\footnotetext{
151 Ibid.

152 Sohail Jaffer (ed), Islamic Investment Banking: Emerging Trends, Developments and Opportunities (Euromoney Institutional Investor PLC, 2010) 358.

153 Ainley et al, above n 150, 8.

${ }^{154}$ Ibid 9.

155 See Discussion Paper (2010), above n 1, 63-4.
} 
London Stock Exchange has raised over US\$34 billion through issuing 49 Islamic bonds;

- educational institutes offering training and courses on Islamic finance. $^{156}$

Unlike the Austrade publication or the Board's discussion paper, the FSA publication discusses Sharī $a$-compliant issues arising from the introduction of Islamic finance products. It notes that, while certain Sharī $a$ scholars may approve some Islamic finance products as $\operatorname{Sharī}^{-} a$ compliant, others may not. As in Australia, this does raise challenges since most financial institutions are in no position to assess which scholarly opinion is the correct one. Instead they tend to follow Sharī ' $a$ standards as outlined by the Sharī 'a supervisory boards set up by the institutions themselves. The FSA publication notes that, ' $\mathrm{i}] \mathrm{t}$ is widely acknowledged that there is a global shortage of experienced professionals in the Islamic finance sector ... the shortage of resources also extends to Sharia scholars who have relevant banking experience'. ${ }^{157}$

The fact that there is a shortage of experienced Sharī' $a$ scholars and professionals in Islamic finance means there is a possibility that the general public and Sharī' $a$ scholars with no in-depth knowledge of Islamic products can either introduce a regime of Islamic law that is non-compliant with $\operatorname{Shari~}^{-} a$, or reject the current Islamic finance products on the market as being nonShari ' $a$-compliant and thus cause confusion and uncertainty. This uncertainty also exists in the UK as evidenced by the fact that the profit mark-up is treated as interest in murābaḥa products for taxation purposes and many murābaha transactions that take place are not Sharī $a$-compliant.

This uncertainty was reflected in the 2002 case of Islamic Investment Company of the Gulf (Bahamas) Ltd v Symphony Gems NV ('Symphony Gems'). ${ }^{158}$ The judgment in this case was the first instance of a Western court of law - in this case the High Court of Justice, Queen's Bench Division Commercial Court of the United Kingdom - ruling on the applicability of a murābaha contract. In this case, the Islamic Investment Company of the Gulf (Bahamas) Ltd ('IICG') entered into a murābaḥa contract with Symphony Gems NV ('Symphony'). Symphony identified precious gems and stones that IICG would purchase and resell to Symphony on a cost plus mark-up basis. The murābaha contract noted

\footnotetext{
156 'UK Excellence in Islamic Finance' (UK Trade and Investment, October 2014) 3 $<$ https://www.gov.uk/government/uploads/system/uploads/attachment_data/file/367154/UKTI _UK_Excellence_in_Islamic_Finance_Reprint_2014_Spread.pdf >.

${ }^{157}$ Ainley et al, above $\mathrm{n} 150$.

158 [2002] All ER (D) 171 (13 February 2002) ('Symphony Gems’).
} 
another purchase contract whereby the IICG would purchase the gems from a supplier, known as Precious and sell them to Symphony. IICG instituted proceedings against Symphony when Symphony did not repay IICG in full, seeking to reclaim the outstanding balance from Symphony. Symphony made several arguments in its defence, but this article will focus on the argument by Symphony that the murābaha contract was not Shari ' $a$-compliant, and that the IICG charter demanded compliance with Islamic law. In fact, the murābaha contract was not compliant with Sharī' $a$ because it ignored the essential requirement that IICG, as the seller, had to own or possess the goods that were for sale. ${ }^{159}$ This is explained below, by the diagrams comparing a Shari ${ }^{-} a$ compliant muräbaha contract (Figure B) with the case of Symphony Gems consisting of a non Sharī $a$-complaint murābaha contract (Figure C):

\section{Figure B}

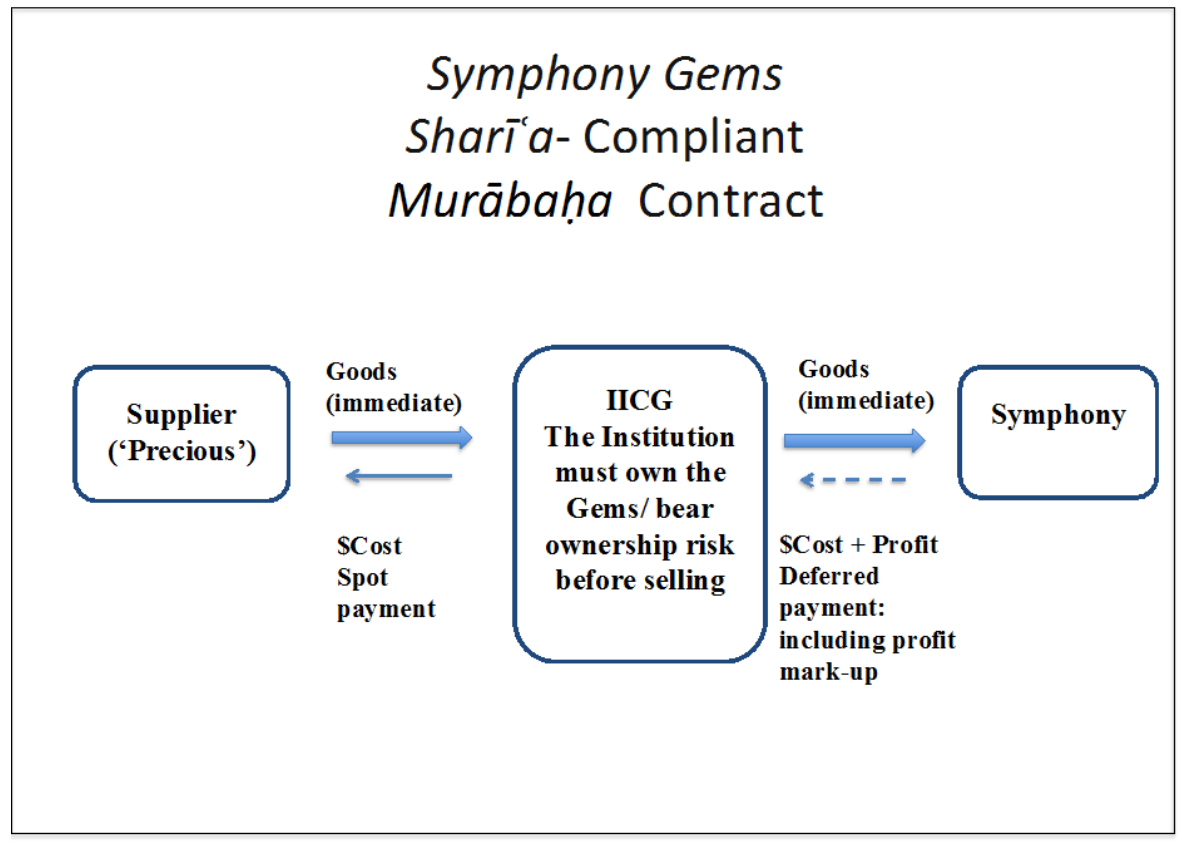

\footnotetext{
159 Umar F Moghul and Arshad A Ahmed, 'Contractual Forms in Islamic Finance Law and Islamic Inv Co of the Gulf (Bahamas) Ltd v Symphony Gems NV \& Ors: A First Impression of Islamic Finance' (2003) 27 Fordham International Law Journal 150, 156.
} 


\section{Figure C}

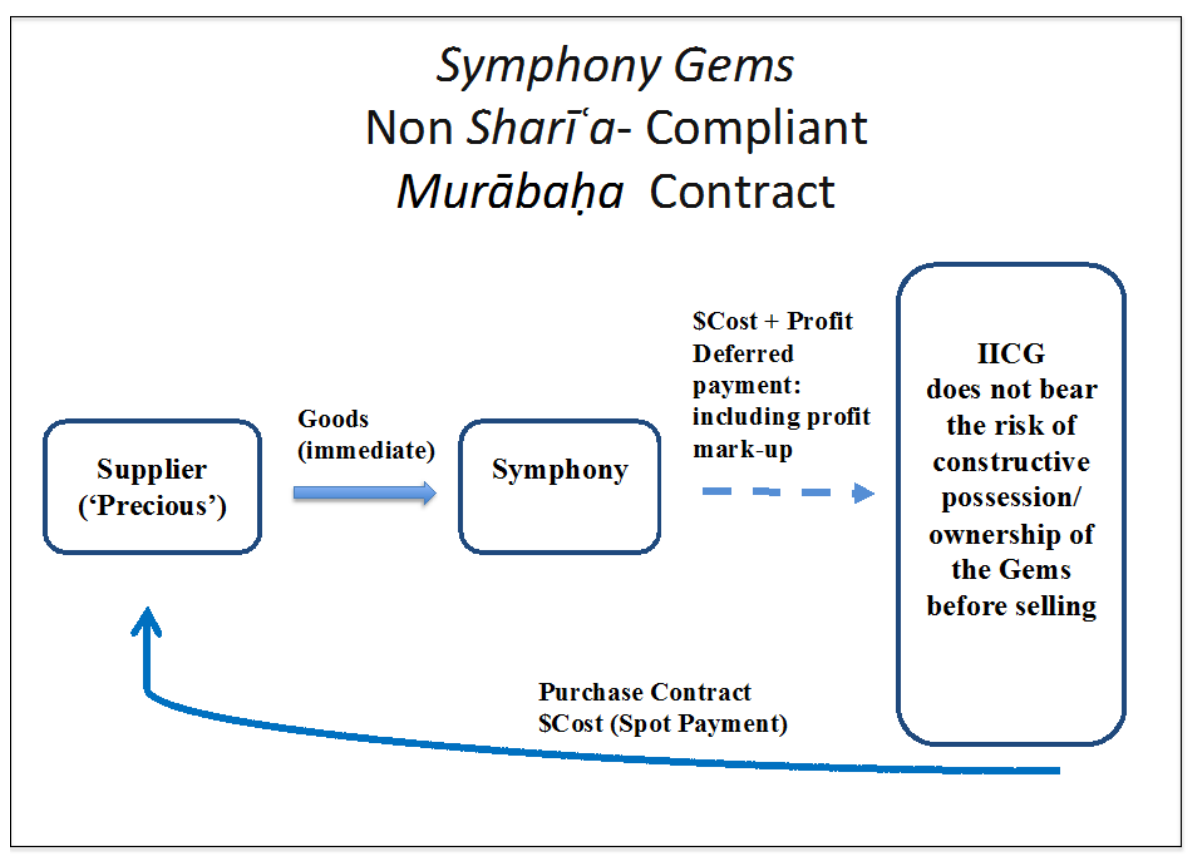

As shown in Figure B, the risk of ownership of the goods is what constitutes a murābaha transaction as Sharī $a$-compliant. By comparison, Figure C shows that in the case of Symphony Gems, the IICG used the supplier, Precious, to send the goods directly to Symphony and therefore the gems were never in IICG's 'constructive possession' which is essentially ownership as discussed above under the definition of murābaha. Symphony also did not have the right to reject the gems if it found that the gems were defective in any way. ${ }^{160}$ Moghul and Ahmed argue:

Though it is possible that Symphony waived its Islamic legal rights and chose to bear these responsibilities itself, it seems more likely, given the circumstances of this case and the superior bargaining posture inherent to commercial banks, that IICG sought to mimic conventional interest-bearing financing to the greatest extent possible by imposing these provisions upon its customer Symphony. ${ }^{161}$

\footnotetext{
${ }^{160}$ Ibid 187.

${ }^{161}$ Ibid 189.
} 
After consulting the $\operatorname{Sharī~}^{`} a$ expert Dr Yahya al-Samaan as an expert witness, Tomlinson J stated:

it is absolutely critical to note ... that the contract with which I am concerned is governed not by Shariah law but by English law. Indeed, it is equally critical to note that Dr. Samaan, after examining the nature and terms of the contract ... comes to this conclusion ... that the Agreement in issue does not have the essential characteristics of a [m] urabaha contract. ${ }^{162}$

Tomlinson $\mathrm{J}$ therefore noted that, while the murābaha contract was not compliant with $\operatorname{Shari}^{-} a$-law, he was bound to assess the case according to English law and not Islamic law. This case provides an example of how a murābaha contract which is not compliant with Sharì 'a may still be enforced in Western jurisdictions if English law applies.

\section{Impact OF INTERNATIONAL Debate in Australia}

Islamic finance is still a novel idea in Australia. According to the 2011 Australian Bureau of Statistics census, approximately 476291 people in Australia are Muslims or 2.2 per cent of the population. ${ }^{163}$ By comparison, Islam is the second largest religion in the UK where the Muslim population is approximately 2.9 million or 4.8 per cent of the total population. ${ }^{164}$ Ahmad, Osmani and Karim note the following:

Skepticism about Sharī 'ah compliant financing and investment products may be a further barrier to the growth of Islamic finance. While Islamic financial services in Australia have been used by members of the Muslim community, and while demand for such services exceeds the supply, not everyone welcomes the growth of Islamic finance. Within Australia's Muslim community there are those who are skeptical about (and in some cases downright hostile to) the first Islamic finance products available to Australian Muslims, questioning the validity of the Sharī'ah-compliant label. ${ }^{165}$

\footnotetext{
162 Islamic Investment Company of the Gulf (Bahamas) Ltd $v$ Symphony Gems NV and others [2002] All ER (D) 171 (13 February, 2002) 6.

163 Australian Bureau of Statistics, Cultural Diversity in Australia Reflecting a Nation: Stories from the 2011 Consensus (21 June 2012) <http://www.abs.gov.au/ausstats/abs@.nsf/ Lookup/2071.0main+features902012-2013>.

${ }^{164}$ Pew Research Centre, above n 148.

165 Abu Umar Faruq Ahmad, Noor Mohammad Osmani and Mohd Fazlul Karim, 'Islamic Finance in Australia: The Potential Problems and Prospects' (Paper presented at Seventh International Conference, The Tawhidi Epistemology: Zakat and Waqf Economy, Malaysia, 6-
} 
However, Ahmad, Osmani and Karim provide no 'direct' or 'empirical' evidence to support their contention regarding the scepticism existing in the Australian Muslim community about Islamic finance products. The only support they provide regarding Muslims' attitudes to the financial products they are being offered is the view of another academic, Ariff, whom they quote as saying:

'Many would say that the Islamic banks are not really different from conventional banks and that they are playing with words and semantics and so on and so forth — coming up with Arabic terms that sound very Islamic but if you scratch it, you will find that it's not that different from conventional financial products. So such concerns do exist., ${ }^{166}$

By contrast, according to the research conducted by Rammal and Zurbruegg only 55.7 per cent of the people surveyed were, in 2007, aware of Islamic banking products in Australia, due to the lack of Islamic finance products offered in Australia and 92.5 per cent said they were keen to switch from conventional to Islamic finance banking products. ${ }^{167}$

It is also clear from the Board's discussion paper that the Australian government and relevant financial institutions are very interested in introducing Islamic finance products to Australia. Although the Australian Muslim population is much smaller than the UK Muslim population, the focus of certain politicians has largely been on providing opportunities for foreign investors to invest in Shari ' $a$-compliant products. ${ }^{168}$ This objective is noted in the Austrade publication titled Islamic Finance (2010) when it refers to attracting investment in Australian assets and businesses from overseas Shariah investors. ${ }^{169}$

7 January 2010) 219, 225 <http://www.ukm.my/hadhari/publication/proceedings-of-seventhinternational-conference-the-tawhidi-epistemology-zakat-and-waqf-economy/> .

${ }^{166}$ Ibid 225.

${ }^{167}$ Hussain Gulzar Rammal and Ralf Zurbruegg, 'Awareness of Islamic Banking Products among Muslims: The Case of Australia' (2007) 12(1) Journal of Financial Services Marketing 65, 702.

${ }^{168}$ It is important to note that support is provided by certain politicians, such as Assistant Treasurer Nick Sherry and Minister Chris Bowen. Islamic finance has not been adopted as the policy of any political party. Furthermore, there have been no further reports discussing Islamic Finance since 2010 which may indicate that support for Islamic Finance has declined. See also Corrs Chambers Westgarth, 'Islamic Finance in Australia Part 3 - What's Stopping Islamic Finance Flourishing Down Under and What Must be Done" (2012) <http://www.corrs. com.au/thinking/insights/islamic-finance-in-australia-part-3-whats-stopping-islamic-financeflourishing-down-under-and-what-must-be-done/>.

${ }^{169}$ Australian Government, Austrade, Islamic Finance (2010) 6 <https://www.google.com.au/ search?q=Islamic+Finance+(2010):+\%E2\%80\%98Attracting+Investment+iIn+Australian+As 
Although another objective of Austrade is to provide Australian Muslims with Shari ${ }^{-} a$-compliant products, it is clear that the Australian government will profit more from attracting international investment than from providing services to Australian Muslims. This is the reason why the then Assistant Treasurer, Nick Sherry, and the then Minister of Financial Services, Superannuation and Corporate Law (9 June 2009-14 September 2010), Chris Bowen, announced in April 2010 that the Board was to undertake a review of Australian tax law in order to ensure that the expansion of Islamic finance is not inhibited. ${ }^{170}$ Furthermore, it is clear from the international discussion of treating mark-up as interest that there has been much debate in Muslim and non-Muslim countries about whether the murābaha product is Sharī $a$ compliant. Therefore, there is a strong possibility that this debate will also occur in Australia as Islamic finance becomes more established and the Australian Muslim population grows. To date, we have not seen much evidence of the existence of such debate among Australian Muslims. In fact, the views of Janson, Clark and Bernardi show that some Australians, perhaps a minority, are still considering whether Sharī $a$-financing is counter to Western values or not.

\section{Conclusion AND Discussion}

There is limited discussion in the Board's discussion paper on the Shari ' $a$ compliance of murābaḥa products, in particular the treatment of profit markup as interest. One of the reasons for the limited discussion is that Islamic finance is still a novel idea in Australia and Islamic banks are yet to be established. The Board's discussion paper was released in late 2010 and no further tax reforms have taken place since the release of the Discussion Paper, while legislative amendments were made to cater for Islamic finance products in the UK as early as 2003. The Board's discussion paper is limited by a number of omissions and unexamined assumptions. First, it contains no discussion by the Board about Sharī'a supervisory boards, and specifically about the differences of opinion by Shari ' $a$ scholars on what constitutes rib $\bar{a}$ and whether 'mark-up' is a form of rib $\bar{a}$. Also, the lack of global expertise on Sharī 'a and global finance means that $\operatorname{Sharī~}^{-} a$ experts need to be trained and educated on global finance and international markets. Second, the Board assumes that there is no problem with treating profit mark-up as interest for taxation purposes,

\footnotetext{
sets+aAnd+Businesses+fFrom+Overseas+Shariah+Investors\%E2\%80\%99+\&ie=utf-8\&oe= utf-8\&gws_rd=cr\&ei=HKYpVqmmJsLO0ASVy5HoBQ\#>.

170 Nick Sherry, 'Board of Taxation to Review Australia's Tax Laws to Ensure Islamic Finance Market can Expand' (Media Release, No 076, 26 April 2010) <http://ministers.treasury.gov .au/DisplayDocs.aspx?doc=pressreleases $/ 2010 / 076$. htm\&pageID $=\& m i n=n j s a \& Y e a r=\& D o c T$ ype $=0>$.
} 
because that is the only way that the tax treatment of murābaha and conventional products will be equal. Third, while the example of the prosperity that Islamic finance has brought in the United Kingdom has been a motivating factor for the introduction of Islamic finance in Australia, there remains considerable debate among Muslim scholars in the UK, many of whom are critical of Islamic finance products such as muräbaha. Further, the Board does not discuss case law in the UK, in particular the case of Symphony Gems, where Justice Tomlinson rejected the defence that the contract Symphony Gems had entered into was not Shari ${ }^{-} a$-compliant in nature. This case is an example of how murābah contracts which are not Shariah-compliant may still be enforced in Western jurisdictions.

While a more detailed analysis of the muräbaha product is needed, there is not enough evidence to suggest that murābaha financing will necessarily be rejected or viewed as not being Sharī $a$-compliant by international Islamic investors and the Australian Muslim community. As Saeed notes, although the profit mark-up in murābaha has been challenged by many as being equivalent to interest, the 'pragmatic approach has persisted'. ${ }^{171}$ This pragmatic approach consists of reading rib $\bar{a}$ contextually in the Qur'an. Therefore, it is argued by those using the contextual approach that 'mark-up' is only riba if it leads to an unjust result. Most international Islamic banks and financial institutions do not view the concept of 'mark-up' as leading to an unjust result, and thus it is not interpreted as riba . Those who interpret ' $r i b \bar{a}$ ' more literally and consider 'mark-up' as being equivalent to rib $\bar{a}$ and clearly prohibited in the Qur'an can choose not to participate in muräbaha transactions. They will, however, be disadvantaged unless they formulate a practical alternative for generating cash and purchasing products and utilities that, in their opinion, is Sharī' $a$ compliant. In conclusion, it is proposed that, before further legislative reforms are introduced in Australia to cater for Islamic finance products, a more thorough analysis of the Sharī $a$-compliant nature of products such as murābaha is required so that any issues in relation to the legitimacy of Islamic finance products under Sharī 'a can be addressed.

\footnotetext{
${ }^{171}$ Saeed, 'Adapting Understanding of Riba to Islamic Banking: Some Developments', above n 50,59 .
} 